\title{
COMPARISON OF CORMACK LEHANE GRADING SYSTEM AND INTUBATION DIFFICULTY SCORE IN PATIENTS INTUBATED BY D-BLADE VIDEO AND DIRECT MACINTOSH LARYNGOSCOPE: A RANDOMIZED CONTROLLED STUDY
}

\author{
Iva Pažur ${ }^{1}$, Branka Maldini ${ }^{1,2}$, Vedran Hostić ${ }^{1}$, Ognjen Ožegić ${ }^{1}$ and Melanija Obraz \\ ${ }^{1}$ Department of Anesthesiology, Intensive Care and Pain Medicine, \\ Sestre milosrdnice University Hospital Center, Zagreb; \\ ${ }^{2}$ Osijek School of Medicine, Josip Juraj Strossmayer University, Osijek, Croatia
}

\begin{abstract}
SUMMARY - D-blade is a relatively new device in the field of videolaryngoscopy, designed for airway management by enabling indirectoscopic glottic view. In our study, we investigated efficiency of D-blade in comparison with direct Macintosh laryngoscope (gold standard). Fifty-two adult patients with normal airway scheduled for elective surgery in general anesthesia were randomly assigned in D-blade video or direct Macintosh group. In the first video group, patients were laryngoscoped and intubated by D-blade, and in the second group laryngoscopy and intubation were performed by Macintosh laryngoscope. Glottic view was evaluated according to Cormack Lehane grading system $(\mathrm{C}-\mathrm{L})$, while duration of intubation and easiness of intubation were evaluated according to the intubation difficulty score (IDS). Additionally, hemodynamic parameters were recorded before and after induction. There were no statistically significant between-group differences in time to intubation, easiness of endotracheal tube insertion, C-L, and IDS. In comparison with direct Macintosh laryngoscope, D-blade showed similar but still favorable characteristics. In our opinion, D-blade is a useful device in airway management and should be used in daily anesthesiologist work.
\end{abstract}

Key words: Endotracheal intubation; Direct laryngoscopy; Airway management; Videolaryngoscopy

\section{Introduction}

There is an era of ongoing development in the field of laryngoscopy and intubation. New devices such as videolaryngoscopes present challenge in everyday work of anesthesiologist, especially in cases where difficult airway management may be expected ${ }^{1-6}$. Despite growing popularity of these devices, only few studies evaluating D-blade videolaryngoscope performance have been conducted to date ${ }^{7-12}$. The aim of this study

Correspondence to: Iva Pažur, MD, Department of Anesthesiology, Intensive Care and Pain Medicine, Sestre milosrdnice University Hospital Center, Vinogradska c. 29, HR-10000 Zagreb, Croatia

E-mail: ivapr3@gmail.com

Received March 17, 2016, accepted June 24, 2016 was to compare C-MAC D-blade with Macintosh laryngoscope in terms of glottis view, time to intubation, intubation difficulty score (IDS) and hemodynamic stability in patients with normal airway scheduled for elective surgical procedure. Our hypothesis was that D-blade would provide better visualization of glottis, shorter duration of intubation, and easier intubation according to IDS $^{13}$ as compared to the Macintosh blade.

\section{Materials and Methods}

The study was conducted in Sestre milosrdnice University Hospital Center from June 2013 until April 2014 after obtaining the institutional ethics board ap- 
proval and patient informed consent. Fifty-two patients undergoing elective surgical procedure were randomly assigned to the $\mathrm{D}$-blade or direct Macintosh group. Inclusion criteria were age $>18$ and physical status I-III according to the American Society of Anesthesiologists (ASA). Exclusion criteria were the presence of three or more predictors for difficult intubation $^{14,15}$, Mallampati test (modified by Samsoon and Young), interincisor gap (IIG), thyromental (TM) distance, upper lip bite test (ULBT), body mass index (BMI), and known previous difficult airway management. Before surgery, patients were premedicated with $5 \mathrm{mg}$ of midazolam intramuscularly. In the operating room, they had intravenous cannule inserted and standard monitoring applied. After preoxigenation via facemask, anesthesia was induced with sufentanyl 0.3 $\mathrm{mcg} / \mathrm{kg}$, propofol $2 \mathrm{mg} / \mathrm{kg}$ and rocuronium $0.6 \mathrm{mg} / \mathrm{kg}$. After achieving proper muscle relaxation, an attempt at intubation was performed with either the $\mathrm{D}$-blade size 4 using a hockey-stick stylet or the Macintosh blade size 3 or 4 with a standard stylet during which the following parameters were obtained: glottic visualization using the Cormack Lehane (C-L) classification $^{16,17}$ and IDS $^{13}$ determined by seven variables:

1) intubation attempts more than one; every advancement of tube toward glottis was considered as an intubation attempt;

2) number of anesthesiologists (representing the number of additional persons directly attempting intubation);

3) number of alternative techniques used;

4) view of glottis according to $\mathrm{C}-\mathrm{L}$ grading system;

5) assessment of lifting force applied during laryngoscopy $(0=$ little force was applied; 1 = great force was applied during laringoscopy based on operator impression);

6) application of external laryngeal pressure $(0=$ there was no pressure applied; 1 = pressure was applied during laryngoscopy); and

7) mobility of vocal cords $(0=$ abduction of vocal cords; 1 = adduction of vocal cords).

The IDS 0 signified easy intubation, 1-5 slightly difficult intubations, $>5$ difficult intubation, and $\infty$ signified impossible intubation. Women in both groups were intubated by endotracheal tube (ETT) of internal diameter (ID) $7.5 \mathrm{~mm}$, and men in both groups were intubated by ETT of ID $8.5 \mathrm{~mm}$. The duration of intubation was recorded from the time the laryngo- scope was taken into the hand until the end tidal carbon dioxide $\left(\mathrm{etCO}_{2}\right)$ curve was displayed on the monitor. After two failed intubation attempts performed by either Macintosh or D-blade, the study was interrupted and the third intubation was performed by Bonfils stylet or fiberbronchoscope. The anesthesiologist who performed intubation noted glottic view using the $\mathrm{C}-\mathrm{L}$ grading system immediately after finishing intubation. Blood pressure and heart rate were recorded one minute before and after intubation in both groups.

\section{Sample size}

Power analysis was performed to determine the sample size needed. Based on standard deviation of time to successful intubation of $13.6 \mathrm{~s}^{18}$, analysis indicated a sample size of 24 patients in each group would provide $80 \%$ power and $5 \%$ level of significance to detect 11 s difference between devices. A decision was made to recruit 26 patients per group to allow dropouts.

\section{Statistics}

Statistical analysis was performed using SPSS v20 (IBM ${ }^{\circledR}$ SPSS ${ }^{\circledR}$ Statistics V20). The $\chi^{2}$-test was used to analyze categorical data (gender and ULBT), Mann-Whitney U test for ordinal data (ASA status, Mallampati test, C-L and IDS), and independent-sample t-test for continuous data (age, BMI, TM, IIG, duration of intubation, MAP and heart rate). A value of $\mathrm{p}<0.05$ was considered significant.

\section{Results}

Demographic and physical airway data are summarized in Table 1 . There were no significant betweengroup differences according to age, gender, ASA physical status, BMI, and physical airway parameters. There were no between-group differences in glottis view, time to intubation and IDS either (Table 2). There was no glottic view of $\mathrm{C}-\mathrm{L}$ grade IV in either group, whereas two patients (7.7\%) in the Macintosh group were assessed as C-L grade III versus none in the D-blade group. All patients were intubated at first attempt. All intubations were determined as easy or slightly difficult. There were no differences in MAP, while heart rate was significantly higher in the D-blade group (Table 3). 
Table 1. Patient characteristics (VL-D-blade group and DL-Macintosh group)

\begin{tabular}{|l|l|l|l|}
\hline & $\begin{array}{l}\text { VL group } \\
(\mathrm{n}=26)\end{array}$ & $\begin{array}{l}\text { DL group } \\
(\mathrm{n}=26)\end{array}$ & $\mathrm{p}$ value \\
\hline Gender (male), n (\%) & $13(50)$ & $15(57.7)$ & 0.579 \\
\hline Age (yrs), mean (SD) & $59(17)$ & $61(12)$ & 0.639 \\
\hline $\begin{array}{l}\text { ASA, n (\%) } \\
\text { I }\end{array}$ & $\begin{array}{l}1(3.8) \\
19(73.1) \\
6(23.1)\end{array}$ & $\begin{array}{l}2(7.7) \\
19(73.1) \\
5(19.2)\end{array}$ & 0.595 \\
III & $\begin{array}{l}17(65.4) \\
8(30.8) \\
1(3.8) \\
\begin{array}{l}\text { Mallampati test, n (\%) } \\
\text { I }\end{array}\end{array}$ & $\begin{array}{l}18(23.1) \\
2(7.7) \\
0(0)\end{array}$ & 0.859 \\
$\begin{array}{l}\text { III } \\
\text { IV }\end{array}$ & $4.7(0.9)$ & $4.7(1.0)$ & 0.869 \\
\hline $\begin{array}{l}\text { Interincisor gap (cm), } \\
\text { mean (SD) }\end{array}$ & $8.3(1.7)$ & $8.6(1.3)$ & 0.546 \\
\hline $\begin{array}{l}\text { Thyromental distance } \\
\text { (cm), mean (SD) }\end{array}$ & $18(69.2)$ & $22(84.6)$ & 0.192 \\
\hline $\begin{array}{l}\text { Upper lip bite test } \\
\text { (yes), n (\%) }\end{array}$ & $27.4(3.9)$ & $25.3(6.8)$ & 0.181 \\
\hline $\begin{array}{l}\text { Body mass index } \\
\text { (kg/m²), mean (SD) }\end{array}$ & & \\
\hline
\end{tabular}

Data are presented as number (\%) or mean (SD); ASA = American Society of Anesthesiologists; $\mathrm{VL}=$ videolaryngoscope; $\mathrm{DL}=$ direct laryngoscope

Table 2. Characteristics of laryngoscopy and intubation (VL-D-blade group and DL-Macintosh group)

\begin{tabular}{|l|l|l|l|}
\hline & $\begin{array}{l}\text { VL group } \\
(\mathrm{n}=26)\end{array}$ & $\begin{array}{l}\text { DL group } \\
(\mathrm{n}=26)\end{array}$ & $\mathrm{p}$ value \\
\hline $\begin{array}{l}\text { Cormack Lehane, } \\
\mathrm{n}(\%) \\
1\end{array}$ & $\begin{array}{l}24(92.3) \\
2(7.7)\end{array}$ & $\begin{array}{l}20(76.9) \\
4(15.4) \\
2\end{array}$ & 0.115 \\
3 & 0 & 0 & \\
4 & 0 & $(7.7)$ & \\
\hline $\begin{array}{l}\text { IDS, n (\%) } \\
0\end{array}$ & $\begin{array}{l}18(69.2) \\
6(23.1)\end{array}$ & $\begin{array}{l}17(65.4) \\
3(11.5)\end{array}$ & 0.508 \\
1 & $2(7.7)$ & $4(15.4)$ & \\
2 & 0 & $2(7.7)$ & \\
3 & 33.6 & $\begin{array}{l}34.3 \\
(15.1)\end{array}$ & 0.883 \\
\hline $\begin{array}{l}\text { Duration } \\
\text { of intubation (s), } \\
\text { mean (SD) }\end{array}$ & $(16.7)$ & (15.1) & \\
\hline
\end{tabular}

Data are presented as number (\%) or mean (SD); IDS = intubation difficulty score; $\mathrm{VL}=$ videolaryngoscope; $\mathrm{DL}=$ direct laryngoscope
Table 3. Hemodynamic records one minute before and one minute after induction (VL-D-blade group and DL-Macintosh group)

\begin{tabular}{|c|c|c|c|}
\hline & $\begin{array}{l}\text { VL group } \\
(\mathrm{n}=26)\end{array}$ & $\begin{array}{l}\text { DL group } \\
(\mathrm{n}=26)\end{array}$ & $\mathrm{p}$ value \\
\hline $\begin{array}{l}\text { Heart rate (beats/min) } \\
\text { - one min before } \\
\text { induction } \\
\text { - one min after } \\
\text { induction }\end{array}$ & $\begin{array}{l}80.5 \\
(11.5) \\
79.7 \\
(13.7)\end{array}$ & $\begin{array}{l}73.2 \\
(11.9) \\
73.9 \\
(15.7)\end{array}$ & 0.029 \\
\hline $\begin{array}{l}\text { MAP }(\mathrm{mm} \mathrm{Hg}) \\
\text { - one min before } \\
\text { induction } \\
\text { - one min after } \\
\text { induction } \\
\end{array}$ & \begin{tabular}{|l}
95.3 \\
$(8.5)$ \\
96.6 \\
$(17.2)$
\end{tabular} & $\begin{array}{l}95.3 \\
(12.8) \\
93.8 \\
(22.9)\end{array}$ & 0.990 \\
\hline
\end{tabular}

Data are presented as mean (SD); VL = videolaryngoscope; $\mathrm{DL}=$ direct laryngoscope; $\mathrm{MAP}=$ mean arterial pressure

\section{Discussion}

The results of our study showed that the D-blade did not offer any advantage for intubation in patients with normal airway since no differences were observed in glottic view, time to intubation and IDS between the groups. However, as opposed to our study, previous larger trials ${ }^{4-8}$ showed better glottic view in patients with normal and difficult airway when using videolaryngoscopy as compared to directoscopy. The simplicity of glottic visualization is not always followed by easy tube insertion and longer intubation time may be required $^{1-3,8,19}$. In the study by Bhat et al. ${ }^{20}$, significantly shorter intubation time was recorded in video group, although intubation was performed in difficult lateral position. Unlike these results, our study showed nonsignificant difference in intubation time, and there were no difficulties in tube insertion despite using different stylets in study groups. The secondary endpoint of our study was evaluation of hemodynamic changes in the video and direct groups. Laryngoscopy and endotracheal intubation are very stressful events and can provoke deleterious hemodynamic disturbances ${ }^{21}$. In terms of hemodynamic stability, both study groups were comparable too, except for heart rate at one minute before intubation in D-blade group. Our findings in terms of hemodynamics are not comparable with literature data, which show that less lifting force applied during videolaryngoscopy consequently provokes less stressful response ${ }^{1-3}$. Additionally, D-blade obvi- 
ates the need of alignment of oral, pharyngeal and laryngeal axis ${ }^{1-3}$ and requires less head and neck manipulations. Siddiqui et al. ${ }^{22}$ found no difference in hemodynamic response between video and direct laryngoscope. Similar results have been reported by Sarkilar et al. in patients scheduled for major cardiac surgery ${ }^{19}$. We may speculate that the only significant finding of hemodynamic instability one minute before intubation in D-blade group could be attributed to the way of anesthetic drug administration during induction and different positioning for $\mathrm{D}$-blade intubation. $\mathrm{Ob}$ vious limitations of our study were the small number of patients and the fact that it included only patients with normal airway, thus there was no unexpected difficult intubation. However, even with these limitations of our study, we think that D-blade is a useful device in airway management and further studies with a greater number of patients including those with difficult airway should be conducted.

\section{Conclusion}

Intubation with video D-blade was comparable to standard direct Macintosh laryngoscope in terms of glottic visualization, duration of intubation, easiness of intubation and hemodynamics. We recommend the introduction of D-blade in everyday work of anesthesiologists, not only in cases where difficult intubation is expected, but also in patients with normal airway.

\section{References}

1. Maldini B, Hodžović I, Goranović T, Mesarić J. Challenges in the use of video laryngoscopes. Acta Clin Croat. 2016;55 Suppl 1:S41-50.

2. Maldini B, Hodžović I, Goranović T. Alternative devices in airway visualization. Acta Clin Croat. 2016;55 Suppl 1:S76-84.

3. Pott ML, Bosseau Murray W. Review of video laryngoscopy and rigid fiberoptic laryngoscopy. Curr Opin Anaesthesiol. 2008;21:750-8. doi: 10.1097/ACO.0b013e3283184227.

4. Stroumpoulis K, Pagoulatou A, Violari M, Ikonomou I, Kalantzi N, Kastrinaki K, et al.Videolaryngoscopy in the management of the difficult airway: a comparison with the Macintosh blade. Eur J Anaesthesiol. 2009;26:218-22. doi: 10.1097/ EJA.0b013e32831e84d1.

5. Marrel J, Blanc C, Frascarolo P, Magnusson L. Videolaryngoscopy improves intubation condition in morbidly obese patients. Eur J Anaesthesiol. 2007;24:1045-9. doi: 10.1017/S0265021 507000889 .
6. Kaplan BM, Hagberg CA, Ward DS, Brambrink A, Chhibber AK, Heidegger T. Comparison of direct and video-assisted views of the larynx during routine intubation. J Clin Anesth. 2006;18:357-62. doi: 10.1016/j.jc linane.2006.01.002.

7. Cavus E, Neumann T, Doerges V, Moeller T, Scharf E, Wagner $\mathrm{K}$, et al. First clinical evaluation of the C-MAC D-Blade videolaryngoscope during routine and difficult intubation. Anesth Analg. 2011;112(2):382-5. doi: 10.1213/ANE.0b013e31820 $553 \mathrm{fb}$.

8. Serocki G, Neumann T, Scharf E, Dorges V, Cavus E. Indirect videolaryngoscopy with C-MAC D-Blade and GlideScope: a randomized controlled comparison in patients with suspected difficult airways. Minerva Anestesiol. 2013;79(2):121-9.

9. Cattano D, Corso RM, Altamirano AV, Patel CB, Meese MM, Seitan C, et al. Clinical evaluation of the C-MAC D-Blade videolaryngoscope in severely obese patients: a pilot study. Br J Anaesth. 2012;109(4):647-8. doi: 10.1093/bja/aes333.

10. Reus E, Akhmetzhanova E, Wrobel M, Grundmann U. Flexible fiberoptic versus hockey stick formed stylet as an intubation guide with the videolaryngoscope $\mathrm{C}-\mathrm{MAC}$ with $\mathrm{D}$-blade. Eur J Anaesthesiol. 2012;29:227.

11. Jain D, Dhankar M, Wig J, Jain A. Comparison of the conventional CMAC and D-Blade CMAC with direct laryngoscopes in simulated cervical spine injury - a manikin study. Braz J Anesthesiol. 2014;64(4):269-74.

12. Batuwitage B, McDonald A, Nishikawa K, Lythgoe D, Mercer $\mathrm{S}$, Charters P. Comparison between bougies and stylets for simulated tracheal intubation with the C-MAC D-blade videolaryngoscope. Eur J Anaesthesiol. 2015;32(6):400-5. doi: 10.1097/EJA.0000000000000070.

13. Adnet F, Borron SW, Racine SX, Clemessy JL, Fournier JL, Plaisance P, et al. The Intubation Difficulty Scale (IDS). Anesthesiology. 1997;87:1273-4.

14. Accorsi A, Adrario E, Agro F, Amicucci G, Antonelli M, Azzeri F, et al. Recommendations for airway control and difficult airway management. Minerva Anestesiol. 2005;71:617-57.

15. Wilson ME, Spiegelhalter D, Robertson JA, Lesser P. Predicting difficult intubation. Br J Anaesth. 1988;61:211-6.

16. Cormack RS, Lehane J. Difficult tracheal intubation in obstetrics. Anaesthesia. 1984;39(11):1105-11.

17. Janssens M, Hartstein G. Management of difficult intubation. Eur J Anaesthesiol. 2001;18:3-12.

18. Teoh WH, Saxena S, Shah MK, Sia AT. Comparison of three videolaryngoscopes: Pentax Airway Scope, C-MAC, Glidescope $v$ s the Macintosh laryngoscope for tracheal intubation. Anaesthesia. 2010;65:1126-32. doi: 10.1111/j.1365-2044.20 10.06513.x.

19. Sarkilar G, Sargin M, Berra Saritaş T, Borazan H, Gök F, Kilicaslan A, et al. Hemodynamic responses to endotracheal intubation performed with video and direct laryngoscopy in patients scheduled for major cardiac surgery. Int J Clin Exp Med. 2015;8(7):11477-83. 
20. Bhat R, Sanickop CS, Patil MC, Vijay US, Dhorigol MG. Comparison of Macintosh laryngoscope and C-MAC video laryngoscope for intubation in lateral position. J Anaesthesiol Clin Pharmacol. 2015;31(2):226-9. doi: 10.4103/0970-9185. 155221.

21. Bruder N, Ortega D, Granthil C. Consequences and prevention methods of hemodynamic changes during laryngoscopy and intratracheal intubation. Ann Fr Anesth Reanim. 1992; 11(1):57-71.

22. Siddiqui N, Katznelson R, Friedeman Z. Heart rate/blood pressure response and airway morbidity following tracheal intubation with direct laryngoscopy, GlideScope and Trachlight: a randomised control trial. Eur J Anaesthesiol. 2009;26(9): 740-5. doi: 10.1097/EJA.0b013e32832b138d.

Sažetak

USPOREDBA D-BLADE VIDEOLARINGOSKOPA

S DIREKTNIM MACINTOSHEVIM LARINGOSKOPOM

PREMA KLASIFIKACIJI CORMACK LEHANE TE LJESTVICI BODOVANJA TEŽINE INTUBACIJE: RANDOMIZIRANO KONTROLIRANO ISTRAŽIVANJE

\section{Pažur, B. Maldini, V. Hostić, O. Ožegić i M. Obraz}

D-blade je relativno nov uređaj na području videolaringoskopije koji omogućava isključivo indirektan prikaz glotisa. U našem istraživanju uspoređivali smo učinkovitost D-blade-a s direktnim Macintoshevim laringoskopom koji predstavlja zlatni standard. Pedeset dvoje bolesnika s normalnim dišnim putem, predviđeni za elektivnu kiruršku operaciju u općoj anesteziji, randomizirano su dodijeljeni u skupinu video D-blade ili direktnog Macintosha. U prvoj skupini bolesnici su bili laringoskopirani i intubirani video D-blade-om, a u drugoj skupini su bili laringoskopirani i intubirani Macintoshevim laringoskopom. Za procjenu prikaza glotisa koristili smo klasifikaciju Cormack Lehane (C-L), dok smo trajanje intubacije i lakoću intubacije procjenjivali koristeći ljestvicu bodovanja težine intubacije (engl. intubation difficulty score, IDS). Hemodinamske parametre smo bilježili prije i nakon indukcije. Između dviju skupina nije bilo statistički značajne razlike u vremenu intubacije, lakoći uvođenja tubusa, klasifikaciji C-L i IDS-u. Prema rezultatima našega istraživanja zaključujemo da u usporedbi s Macintoshevim laringoskopom D-blade pokazuje povoljne karakteristike te bi mogao biti uveden u svakodnevni rad anesteziologa.

Ključne riječi: Endotrahealna intubacija; Direktna laringoskopija; Zbrinjavanje dišnog puta; Videolaringoskopija 